\title{
Stimulation of DNA Glycosylase Activities by XPC Protein Complex: Roles of Protein-Protein Interactions
}

\author{
Yuichiro Shimizu, ${ }^{1,2}$ Yasuhiro Uchimura, ${ }^{3}$ Naoshi Dohmae, ${ }^{4}$ Hisato Saitoh, ${ }^{3}$ \\ Fumio Hanaoka, ${ }^{1,2}$ and Kaoru Sugasawa ${ }^{1,5}$ \\ ${ }^{1}$ Cellular Physiology Laboratory, RIKEN Discovery Research Institute, Wako, Saitama 351-0198, Japan \\ ${ }^{2}$ Graduate School of Frontier Biosciences, Osaka University, Suita, Osaka 565-0871, Japan \\ ${ }^{3}$ Department of Biological Sciences, Graduate School of Science and Technology, Kumamoto University, Kumamoto 860-8555, Japan \\ ${ }^{4}$ Biomolecular Characterization Team, RIKEN Discovery Research Institute, Wako, Saitama 351-0198, Japan \\ ${ }^{5}$ Biosignal Research Center, Organization of Advanced Science and Technology, Kobe University, Kobe, Hyogo 657-8501, Japan
}

Correspondence should be addressed to Kaoru Sugasawa, ksugasawa@garnet.kobe-u.ac.jp

Received 30 April 2010; Accepted 9 June 2010

Academic Editor: Ashis Basu

Copyright ( 2010 Yuichiro Shimizu et al. This is an open access article distributed under the Creative Commons Attribution License, which permits unrestricted use, distribution, and reproduction in any medium, provided the original work is properly cited.

\begin{abstract}
We showed that XPC complex, which is a DNA damage detector for nucleotide excision repair, stimulates activity of thymine DNA glycosylase (TDG) that initiates base excision repair. XPC appeared to facilitate the enzymatic turnover of TDG by promoting displacement from its own product abasic site, although the precise mechanism underlying this stimulation has not been clarified. Here we show that XPC has only marginal effects on the activity of E. coli TDG homolog (EcMUG), which remains bound to the abasic site like human TDG but does not significantly interacts with XPC. On the contrary, XPC significantly stimulates the activities of sumoylated TDG and SMUG1, both of which exhibit quite different enzymatic kinetics from unmodified TDG but interact with XPC. These results point to importance of physical interactions for stimulation of DNA glycosylases by XPC and have implications in the molecular mechanisms underlying mutagenesis and carcinogenesis in XP-C patients.
\end{abstract}

\section{Introduction}

DNA, which carries the genetic information, is liable to alterations by various agents of endogenous and environmental origin. In order to prevent the deleterious effects yielded by such DNA lesions and to maintain the integrity of the genome and cellular functions, cells are equipped with several DNA repair systems, such as base excision repair (BER), nucleotide excision repair (NER), and mismatch repair (for review, see [1]). BER is one of the most versatile repair pathways that can deal with base lesions resulting mainly from alkylation, oxidation, deamination, and replication errors. This pathway is initiated by damage-specific DNA glycosylases that release the altered or inappropriate bases by cleavage of the $\mathrm{N}$-glycosylic bond from the phosphatesugar backbone, thereby resulting in production of the apurinic/apyrimidinic (AP) sites (reviewed in $[2,3]$ ). The phosphodiester bond $5^{\prime}$ to the AP site is then nicked by
AP endonucleases. A class of DNA glycosylases, designated bifunctional DNA glycosylases, possess additional AP lyase activity that further cleaves the phosphodiester bond $3^{\prime}$ to the AP site generated by its own glycosylase activity. When BER is initiated by such bifunctional DNA glycosylases, AP endonuclease removes $3^{\prime}$-unsaturated aldehyde left behind by the AP lyase activity. As a consequence of either pathways, $3^{\prime}-\mathrm{OH}$ end is generated which is suitable for the following DNA repair synthesis.

Unlike BER that mainly repairs base lesions, NER deals with a wide variety of helix-distorting lesions, including ultraviolet (UV) light-induced pyrimidine photodimers as well as intrastrand crosslinks and bulky adducts induced by numerous chemical compounds. Xeroderma pigmentosum (XP) is one of the autosomal recessive disorders that are associated with defective NER and clinically characterized by severe photosensitivity against UV exposure and a high risk of skin cancer. To date, seven NER-deficient XP 
5' - GGCCAGTGAATTCCCGGGGATCCGTCGACCTGCAGCCAAGCTTGGCGTAATCATGGTCAT - $3^{\prime}$

$3^{\prime}$ - CCGGTCACTTAAGGGCCCCTAGGCAGXTGGACGTCGGTTCGAACCGCATTAGTACCAGTA - 5'

$$
(\mathrm{X}=\mathrm{T} \text { or } \mathrm{U})
$$

(a) G/T or G/U (60 bp)

5' - CTCGTCAGCATCTUGATCATACAGTCAGTG - 3'

(b) $\mathrm{ss}-\mathrm{U}(30 \mathrm{mer})$

FIgURE 1: DNA substrates used in this study.

genetic complementation groups have been identified (XPA through $-G)$, for each of which the responsible gene has been cloned [4]. Unlike most of the other XP groups, XP-C patients show defects only in one of the two NER subpathways, that is, global genome NER that covers the entire genome. The other subpathway is referred to as transcription-coupled NER, which repairs transcriptionblocking lesions on the transcribed strand of active genes. The XPC protein, the responsible gene product for the XP group C, plays an essential role in DNA damage recognition and the following initiation of global genome NER [57]. It forms in vivo a stable heterotrimeric complex with either RAD23A or RAD23B, one of the two mammalian homologues of Saccharomyces cerevisiae Rad23p, and centrin 2 , which is known also as a component of the centrosome [8-10]. RAD23 stabilizes the XPC protein in vivo $[11,12]$, and the XPC-RAD23 heterodimer is sufficient to reconstitute the cell-free NER reaction [13, 14], whereas centrin 2 appears to potentiate the damage-specific DNA binding activity of the XPC complex [15]. Biochemical and structural analyses revealed that this complex recognizes a specific DNA secondary structure containing a junction between doublestranded DNA and a single-stranded 3'-overhang [16-18]. After the DNA binding by XPC, ATPase/helicase activities of TFIIH (exerted by the XPB and XPD subunits) open DNA duplex and demarcate damage, probably with the aid of XPG, $\mathrm{XPA}$, and replication protein A (RPA). The damaged strand is then cleaved in both sides of the lesion by two structurespecific NER endonucleases, ERCC1-XPF and XPG, and the resulting gap is refilled with the DNA repair synthesis [19].

We have previously shown that XPC interacts directly with one of the DNA glycosylases, thymine DNA glycosylase (TDG) [20]. TDG removes thymine or uracil residues from $\mathrm{G} / \mathrm{T}$ or $\mathrm{G} / \mathrm{U}$ mismatches, which are mainly derived from hydrolytic deamination of 5-methylcytosines or cytosines, respectively (for review, see [21]). TDG is unique in that it cannot dissociate from the substrate DNA by itself after accomplishing its enzymatic activity [22, 23]. Crystal structure of the E. coli homolog of TDG, the mismatchspecific uracil DNA glycosylase (EcMUG), demonstrated that the inability to turnover is due to its tight interaction with the guanine opposite the AP site $[24,25]$. Extensive biochemical analyses have suggested that this feature may be applicable also to the human TDG $[22,23,26]$. Since continuous attachment of TDG to AP sites must interfere with the following BER process, it has been conceivable that there should be certain factors that promote dissociation of TDG from the processed DNA. One candidate for such factors relieving TDG of the product inhibition is AP endonuclease 1 (APE1), which acts in the BER pathway immediately after the DNA glycosylases [22, 27-29]. Another factor would be sumoylation of TDG, which occurs at a single specific site (Lys330 in human TDG) [30]. The Xray crystal structure of sumoylated TDG revealed that this modification induces a significant conformational change in the C-terminal domain of TDG, which seems to sterically prevent its interaction with DNA [31]. Thus, it has been proposed that the sumoylation following base excision may promote the enzymatic turnover of TDG [32], although precise timing and regulation of the modification in vivo still remain to be elucidated. In addition, we have previously shown that XPC-RAD23B forms a ternary complex with TDG bound to the substrate DNA and promote dissociation of TDG from the AP site [20]. Like TDG and APE1, XPC can recognize and bind to AP sites, although the observed affinity is relatively low if opposite base is guanine [20]. Therefore, two notions have been conceivable concerning molecular mechanisms underlying the stimulation of TDG turnover by XPC: direct physical interaction and competition for the AP site. More recently, it has been reported that XPC interacts with and stimulates the activity of OGG1, a major DNA glycosylase that removes various oxidative base lesions including 8-oxoguanine [33]. Here we further investigate possible involvement of the XPC protein complex in BER by using various DNA glycosylases as well as a sumoylated form of TDG, which gives further insights to the molecular mechanisms for the TDG stimulation.

\section{Materials and Methods}

2.1. Purification of Recombinant Proteins. Purification of recombinant human XPC and His-tagged RAD23B (RAD23B-His) was carried out [34, 35], and the XPCRAD23B-His heterodimer was reconstituted in vitro as described previously [17]. His-TDG, GST-TDG, GST, and His-SMUG1 were also purified as described elsewhere $[20,36]$.

EcMUG and UNG2, both fused to the N-terminal Histag, were expressed in E. coli strain BL21 (DE3) using the pET-28a vector (Novagen). Expression of His-EcMUG was induced with $1 \mathrm{mM}$ isopropyl- $\beta$-D-thiogalactopyranoside (IPTG) at $37^{\circ} \mathrm{C}$ for 3 hours. The bacterial cell pellets were sonicated in buffer A $[25 \mathrm{mM}$ sodium phosphate ( $\mathrm{pH} 7.5)$, $1 \mathrm{mM}$ EDTA, $25 \mathrm{mM} \mathrm{NaCl}, 0.01 \%$ Nonidet P-40, $1 \mathrm{mM}$ dithiothreitol (DTT), $0.25 \mathrm{mM}$ phenylmethylsulfonyl fluoride (PMSF), protease inhibitor cocktail (Complete; Roche Diagnostics)] and centrifuged for 30 minutes at 100,000 g. 


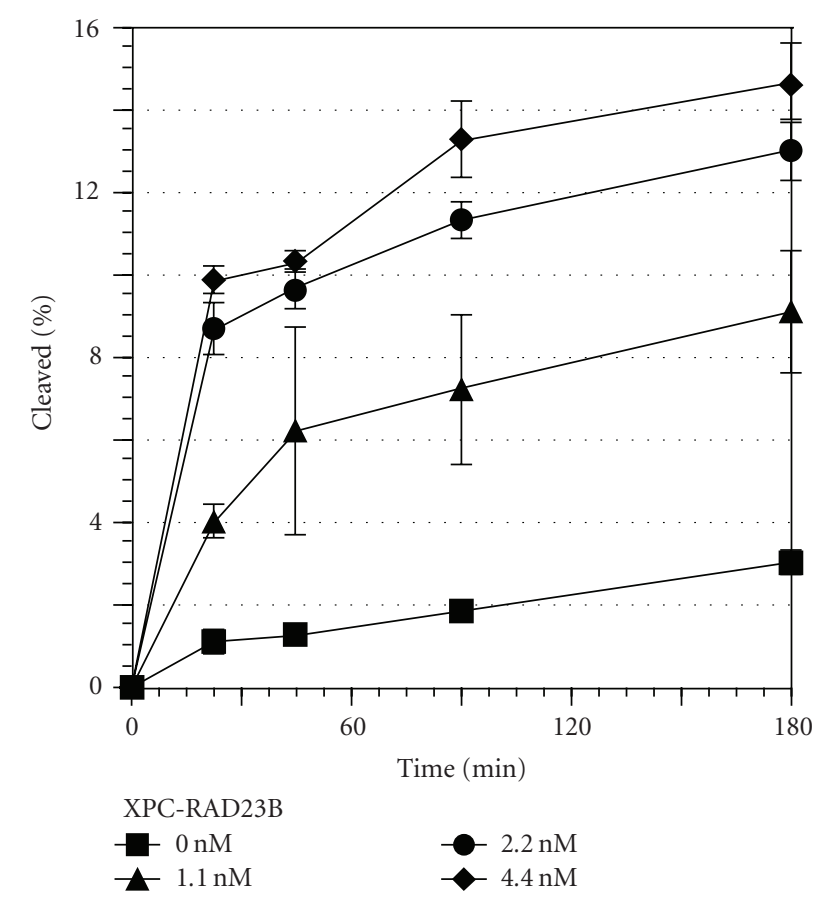

FIgURE 2: XPC stimulates the activity of TDG that cleaves uracil from $\mathrm{G} / \mathrm{U}$ mismatches. The activity of TDG was measured by using $1.6 \mathrm{nM}$ of $60-\mathrm{bp}$ DNA containing a single $\mathrm{G} / \mathrm{U}$ mismatch as a substrate. The reaction was done at $30^{\circ} \mathrm{C}$ for the indicated time with $0.42 \mathrm{nM}$ His-TDG in the presence of various concentrations of XPC-RAD23B. The DNA samples were then purified and subjected to alkali-treatment to cleave the resulting AP sites and separated with denaturing PAGE. The ratio of the cleaved product was calculated and plotted as a graph. The mean values and standard errors were calculated from at least two independent experiments.

The supernatant was loaded onto a phosphocellulose column (P-11; Whatman) equilibrated with buffer B [20 mM sodium phosphate ( $\mathrm{pH} 7.5), 10 \%$ glycerol, $0.01 \%$ Triton X-100, $0.25 \mathrm{mM}$ PMSF] containing $0.1 \mathrm{M} \mathrm{NaCl}$. After the resin was washed thoroughly with the same buffer, bound proteins were eluted stepwise with buffer B containing 0.2 and $1 \mathrm{M}$ $\mathrm{NaCl}$. Proteins recovered in the $1 \mathrm{M} \mathrm{NaCl}$ fraction were then applied to a column packed with TALON resin (Clontech) equilibrated with buffer $\mathrm{C}[20 \mathrm{mM}$ Tris- $\mathrm{HCl}$ ( $\mathrm{pH} 7.5)$, $10 \%$ glycerol, $0.1 \mathrm{M} \mathrm{NaCl}, 0.01 \%$ Triton X-100, $0.25 \mathrm{mM}$ PMSF] containing $5 \mathrm{mM}$ imidazole. The column was then washed extensively with the same buffer, followed by stepwise elution of the bound proteins with buffer $\mathrm{C}$ containing 20, 100 , and $250 \mathrm{mM}$ imidazole. Finally, the $100 \mathrm{mM}$ imidazole fraction containing His-EcMUG was dialyzed against buffer D [20 mM sodium phosphate ( $\mathrm{pH}$ 7.5), $1 \mathrm{mM}$ EDTA, 10\% glycerol, $0.01 \%$ Triton X-100, $1 \mathrm{mM}$ DTT, $0.25 \mathrm{mM}$ PMSF] containing $0.2 \mathrm{M} \mathrm{NaCl}$.

Expression of His-UNG2 was induced with $1 \mathrm{mM}$ IPTG at $30^{\circ} \mathrm{C}$ for 3 hours. The bacterial cell extract was prepared as described above and loaded onto a HiLoad 16/10 SP Sepharose HP column (GE Healthcare Biosciences) equilibrated with buffer B containing $0.1 \mathrm{M} \mathrm{NaCl}$. After washing the resin with the same buffer, bound proteins were eluted

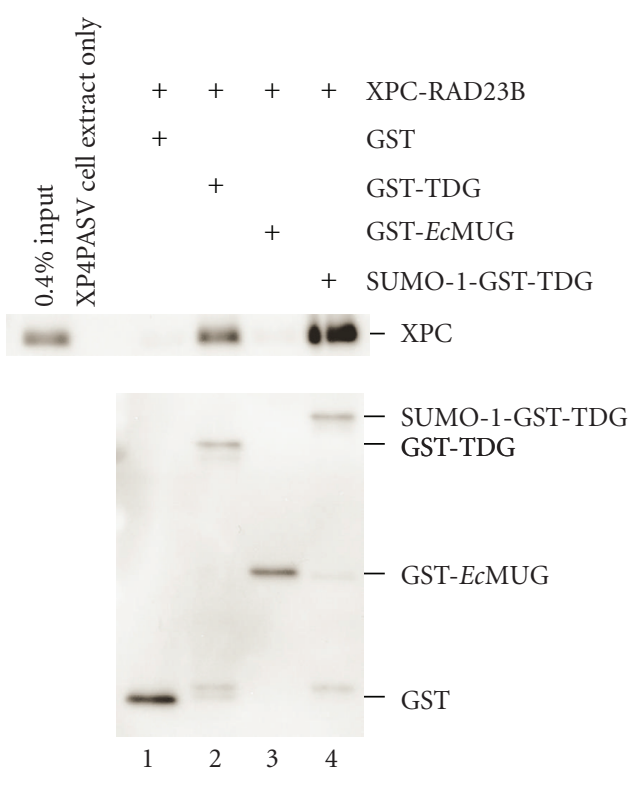

FIGURE 3: XPC physically interacts with SUMO-1-conjugated TDG, but not with EcMUG. Glutathione-Sepharose beads $(20 \mu \mathrm{l})$ were incubated in $100 \mu \mathrm{l}$ of the binding mixture containing $10 \mathrm{nM}$ of GST (negative control), GST-TDG (positive control), GST-EcMUG, or SUMO-1-GST-TDG in the presence of the same concentration of XPC-RAD23B. After extensive washing, bound proteins were eluted with buffer containing $10 \mathrm{mM}$ glutathione. One-fourth of each eluate was mixed with whole cell extract from XP4PASV cells which do not express XPC and subjected to 8\% SDS-PAGE followed by immunoblotting with anti-XPC antibody (upper panel). The same samples were also subjected to $12 \%$ SDS-PAGE followed by immunoblotting with anti-GST antibody (lower panel).

stepwise with buffer B containing 0.5 and $1 \mathrm{M} \mathrm{NaCl}$. HisUNG2 recovered in the $0.5 \mathrm{M} \mathrm{NaCl}$ fraction was further purified with TALON resin, exactly as described above for His-EcMUG. The $250 \mathrm{mM}$ imidazole fraction was then loaded onto a Mono S PC 1.6/5 column equilibrated with buffer D containing $0.1 \mathrm{M} \mathrm{NaCl}$. The column was developed with a linear gradient of $0.1-0.7 \mathrm{M} \mathrm{NaCl}$ in buffer $\mathrm{D}$ and HisUNG2 was eluted around $0.4 \mathrm{M} \mathrm{NaCl}$. Finally, the sample was subjected to gel filtration chromatography using a Superdex 75 PC 3.2/30 column (GE Healthcare Biosciences) equilibrated with buffer D containing $0.2 \mathrm{M} \mathrm{NaCl}$.

Sumoylation of His-TDG was conducted in E. coli strain BL21 (DE3) as described [37]. After induction of protein expression with $1 \mathrm{mM}$ IPTG at $30^{\circ} \mathrm{C}$ for 3 hours, bacterial cell extract was prepared and fractionated on SP Sepharose and TALON columns exactly as described above for HisUNG2. The $250 \mathrm{mM}$ imidazole fraction from the TALON column containing SUMO-1-His-TDG was subsequently loaded onto a Mono Q HR 5/5 column (GE Healthcare Biosciences) equilibrated with buffer E $[20 \mathrm{mM}$ Tris- $\mathrm{HCl}$ (pH 7.5), $1 \mathrm{mM}$ EDTA, $10 \%$ glycerol, $0.01 \%$ Triton X-100, $1 \mathrm{mM}$ DTT, $0.25 \mathrm{mM}$ PMSF] containing $0.1 \mathrm{M} \mathrm{NaCl}$. The column was developed with a linear gradient of $0.1-0.5 \mathrm{M}$ $\mathrm{NaCl}$ in buffer $\mathrm{E}$ and SUMO-1-His-TDG was eluted around 


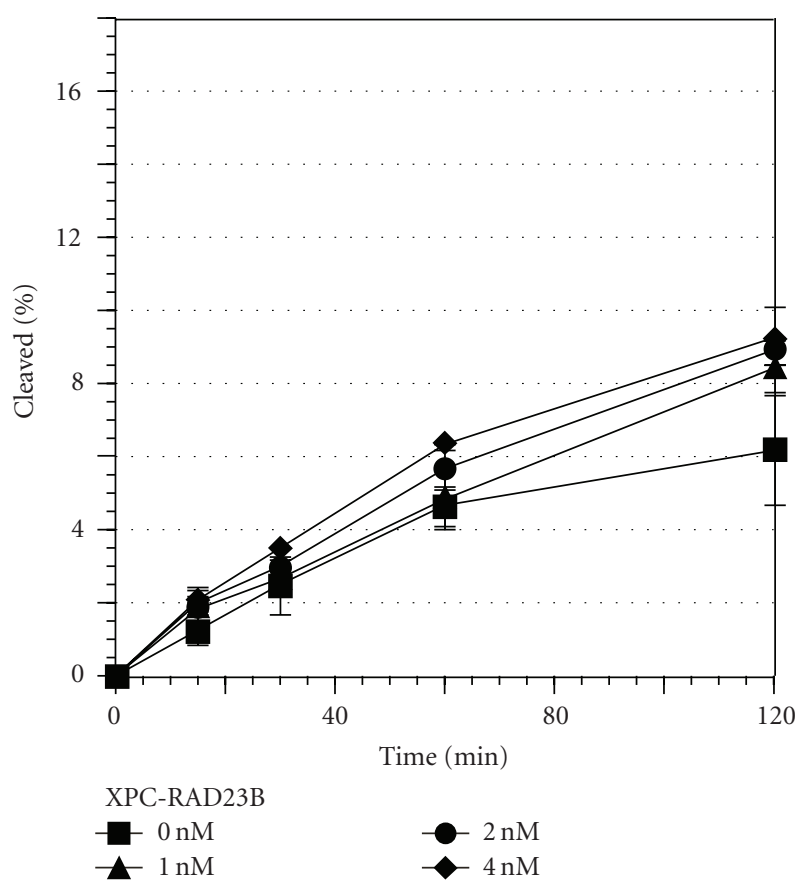

FIGURE 4: The effect of XPC on the activity of EcMUG that cleaves uracil from G/U mismatches. The activity of EcMUG was measured by using $1.6 \mathrm{nM}$ of 60 -bp DNA containing a single $\mathrm{G} / \mathrm{U}$ mismatch as a substrate. The reaction was done at $30^{\circ} \mathrm{C}$ for the specified time with $0.8 \mathrm{nM}$ His-EcMUG and indicated concentrations of XPCRAD23B. The DNA samples were then purified and subjected to alkali-treatment to cleave the resulting AP sites and separated with denaturing PAGE. The ratio of the cleaved product was calculated and plotted as a graph. The mean values and standard errors were calculated from at least two independent experiments.

0.2 M NaCl. Finally, proteins were loaded onto a Mono S PC 1.6/5 column equilibrated with buffer $\mathrm{D}$ containing $0.1 \mathrm{M}$ $\mathrm{NaCl}$ and then eluted with a linear gradient of $0.1-0.5 \mathrm{M}$ $\mathrm{NaCl}$ in buffer D. SUMO-1-His-TDG was collected from the fractions around $0.2 \mathrm{M} \mathrm{NaCl}$.

GST-fusion proteins were expressed in E. coli strain BL21 (DE3) using the expression vector pGEX4T3 and purified through two successive chromatography procedures using a GSTrap column (GE Healthcare Biosciences) and then a Mono S PC 1.6/5 column.

Flag-tagged MBD4 (Flag-MBD4) was expressed in insect cells using the Bac-to-Bac baculovirus expression system (Invitrogen). High Five cells were infected with the recombinant baculovirus, and proteins were extracted from the cells with buffer F [25 mM Tris- $\mathrm{HCl}$ ( $\mathrm{pH} 8.0$ ), 1 mM EDTA, $0.3 \mathrm{M} \mathrm{NaCl}, 10 \%$ glycerol, $1 \%$ Nonidet P-40, $1 \mathrm{mM}$ DTT, $0.25 \mathrm{mM}$ PMSF, protease inhibitor cocktail (Complete)] and dialyzed against buffer D containing $0.1 \mathrm{M} \mathrm{NaCl}$. Samples were then loaded onto a HiLoad 16/10 SP Sepharose HP column (GE Healthcare Biosciences) equilibrated with buffer D containing $0.1 \mathrm{M} \mathrm{NaCl}$. After washing the column with the same buffer, bound proteins were eluted stepwise with buffer $\mathrm{D}$ containing 0.5 and $1 \mathrm{M} \mathrm{NaCl}$. The $0.5 \mathrm{M} \mathrm{NaCl}$ fraction was subsequently loaded to an anti-Flag M2-agarose column
(Sigma-Aldrich) and eluted with buffer D plus $1 \mathrm{M} \mathrm{NaCl}$ and $0.1 \mathrm{mg} / \mathrm{ml} 3 x$ Flag-peptide (Sigma-Aldrich). The eluate was adjusted at $0.3 \mathrm{M} \mathrm{NaCl}$ by dilution with buffer $\mathrm{B}$ and then loaded to a HiTrap heparin HP column (GE Healthcare Biosciences) equilibrated with buffer D containing $0.3 \mathrm{M}$ $\mathrm{NaCl}$. Bound proteins were eluted stepwise with buffer D containing 0.5 and $1 \mathrm{M} \mathrm{NaCl}$, and Flag-MBD4 appeared in the $1 \mathrm{M} \mathrm{NaCl}$ fraction. Finally, the fraction was diluted by buffer $\mathrm{D}$ in order to decrease the $\mathrm{NaCl}$ concentration to $0.3 \mathrm{M}$ again and subjected to a Mono S PC 1.6/5 column equilibrated with buffer $\mathrm{D}$ containing $0.3 \mathrm{M} \mathrm{NaCl}$. The elution of the bound protein was conducted with a linear gradient of $0.3-1 \mathrm{M} \mathrm{NaCl}$ in buffer $\mathrm{D}$, where Flag-MBD4 was collected from the fractions around $0.5 \mathrm{M} \mathrm{NaCl}$.

2.2. Nicking Assay. The enzymatic activities of DNA glycosylases in the presence or absence of XPC-RAD23B were measured as described previously [20]. Substrates used (G/T, $\mathrm{G} / \mathrm{U}$, and ss-U) are shown in Figure 1.

2.3. GST Pull-Down Assay. Glutathione-Sepharose 4 fast flow (GE Healthcare Biosciences: $20 \mu \mathrm{l}$ ) was mixed with recombinant proteins as indicated in $100 \mu \mathrm{l}$ of the binding buffer $20 \mathrm{mM}$ sodium phosphate ( $\mathrm{pH} 7.4$ ), $1 \mathrm{mM}$ EDTA, $150 \mathrm{mM} \mathrm{NaCl}, 1 \mathrm{mM}$ DTT, 5\% glycerol, 0.01\% Triton X-100, $100 \mu \mathrm{g} / \mathrm{ml}$ bovine serum albumin. After incubation on ice for 1 hour with occasional agitation, the beads were washed eight times with $500 \mu \mathrm{l}$ of the binding buffer and the proteins retained on the beads were eluted using $20 \mu \mathrm{l}$ of the binding buffer containing $10 \mathrm{mM}$ glutathione. Since purified XPC has a tendency to aggregate when boiled in the presence of SDS, each eluate was mixed before denaturation with the whole cell extract $(0.4 \mu \mathrm{g}$ protein) from XP4PASV cells that do not express endogenous XPC [20]. An aliquote of each eluate mixed with XP4PASV cell extract was subjected to $8 \%$ SDSPAGE and analyzed by immunoblotting using polyclonal anti-XPC or anti-GST antibodies.

2.4. Antibodies. The polyclonal antibodies against XPC and TDG were raised as described previously [20, 35]. The polyclonal anti-GST (GE Healthcare Biosciences) and antiSUMO-1 (Santa Cruz Biotechnology) antibodies were purchased.

\section{Results}

3.1. XPC Stimulates the Repair of $G / U$ Mismatches Initiated by TDG. We first examined whether XPC can stimulate the enzymatic activity of TDG that removes uracils from the G/U mismatches by the conventional DNA glycosylase assay involving the substrate shown in Figure 1(a). We have previously shown by using the DNA substrate containing a single G/T mismatch that XPC-RAD23B stimulates the activity of TDG by promoting dissociation of the enzyme from the AP site [20]. Although TDG has been shown to exhibit significantly higher activity with $G / U$ than $G / T$ mismatches, the severe product inhibition has been also observed with the G/U substrate [23]. In this point of 


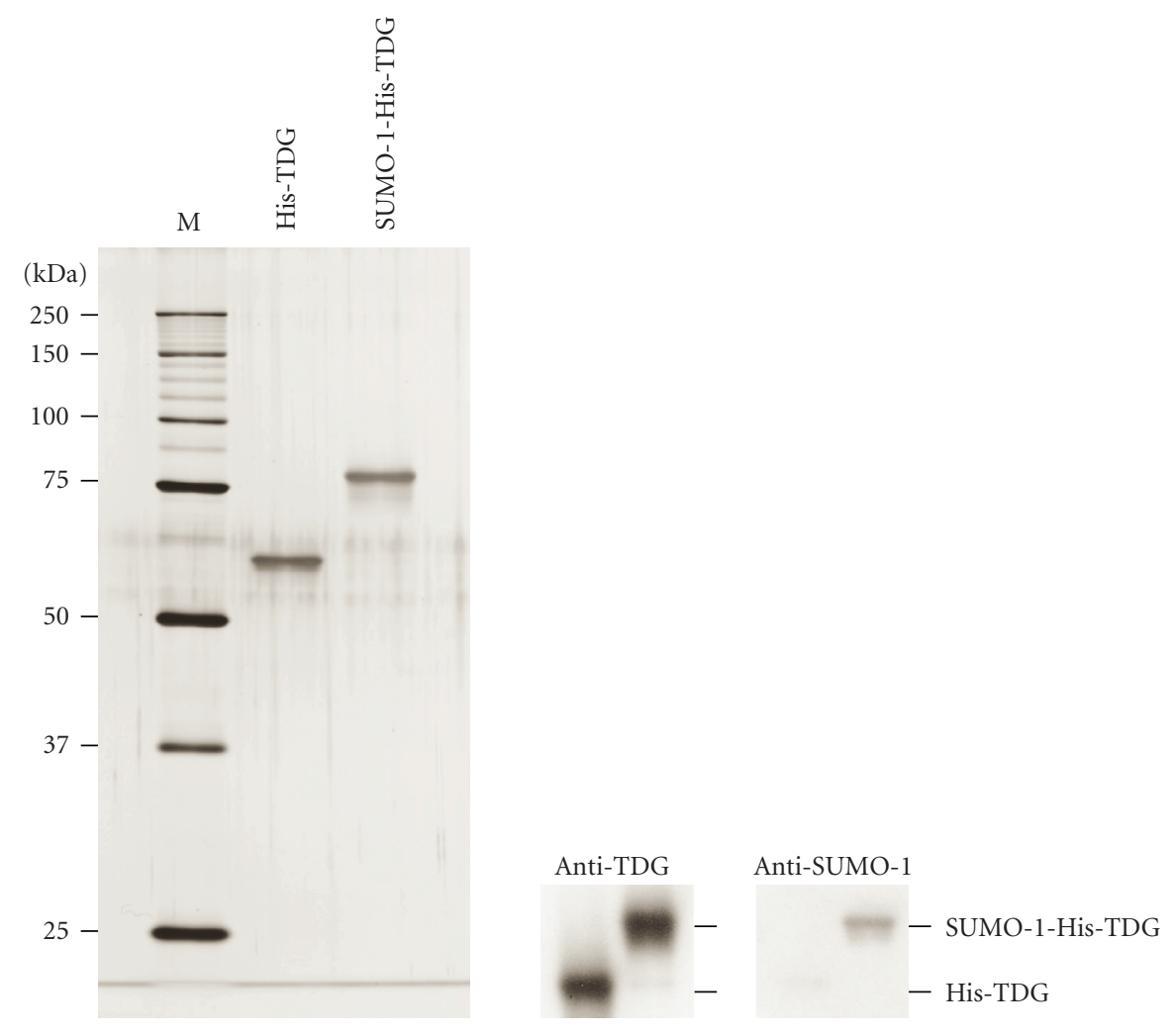

(a)

(b)

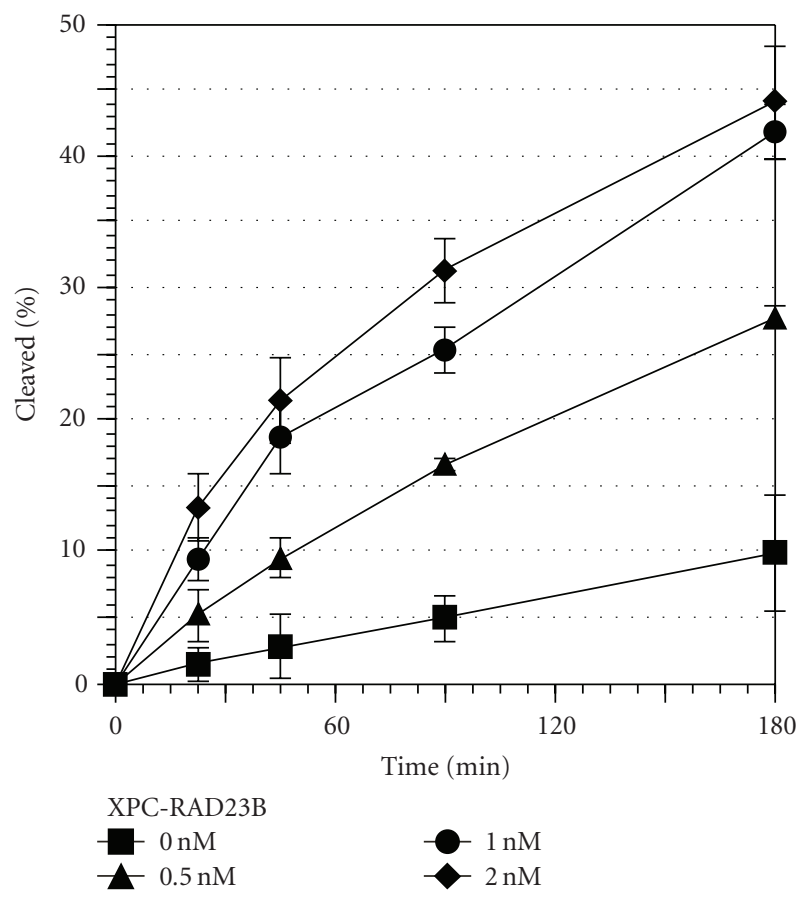

(c)

Figure 5: The effect of XPC on the activity of SUMO-1-modified TDG that cleaves uracil from G/U mismatches. (a) Silver staining of the purified recombinant nonmodified His-TDG and SUMO-1-modified His-TDG. M represents the size marker. (b) The sumoylation of TDG was verified with western blot analyses using anti-TDG antibody (left) or anti-SUMO-1 antibody (right). (c) The activity of sumoylated His-TDG was measured by using $1.6 \mathrm{nM}$ of 60 -bp DNA containing a single $\mathrm{G} / \mathrm{U}$ mismatch as a substrate. The reaction was done at $30^{\circ} \mathrm{C}$ for the time indicated with $2 \mathrm{nM}$ SUMO-1-conjugated His-TDG in the presence of XPC-RAD23B. The DNA samples were then purified and subjected to alkali-treatment to cleave the resulting AP sites and separated with denaturing PAGE. The ratio of the cleaved product was calculated and plotted as a graph. The mean values and standard errors were calculated from at least two independent experiments. 
view, the effect of XPC on TDG may be similar regardless of which substrate is used, because the AP site opposite guanine is in any way produced as a result of the enzymatic action. Compared with the reaction kinetics of TDG alone, addition of XPC-RAD23B stimulated the activity of TDG on G/U mismatches up to 5-fold in a dose-dependent manner (Figure 2), exactly as expected.

3.2. XPC Has Only a Marginal Effect on the Activity of E. coli Homolog of TDG. In order to test the significance of protein-protein interaction between XPC and TDG for the stimulation, we purified an E. coli homolog of TDG, the mismatch-specific uracil-DNA glycosylase (EcMUG) [38]. Unlike TDG, which is involved in correction of both G/T and G/U mismatches, EcMUG is primarily G/U-specific, with very low activity toward G/T mismatches [24]. However, EcMUG resembles human TDG in that, after cleavage of the particular bases, it remains tightly bound to the AP site generated after exhibiting the glycosylase activity [2225]. We first tested the presence or absence of physical interaction between XPC and EcMUG fused to glutathione S-transferase (GST-EcMUG). Ten nanomolar each of GSTEcMUG, GST-TDG as a positive control, or GST alone as a negative control was mixed with the equal concentration of XPC-RAD23B, and proteins were pulled down with glutathione-Sepharose beads. Immunoblot analyses revealed that a significant amount of XPC was bound to GST-TDG whereas only little amount of XPC was bound to GST alone as expected (Figure 3, compare lanes 1 and 2; see also [20]). It should be noted that the amount of GST-TDG recovered in the bound fraction was only $\sim 20 \%$ of GST. Meanwhile, the binding between XPC and EcMUG was as much as the background level (Figure 3, compare lanes 1 to 3), indicating that XPC-RAD23B does not interact with EcMUG in vitro under the conditions tested.

We next added XPC into the nicking assay using the G/U substrate in order to see whether it influences the activity of EcMUG. Although significant physical interaction could not be detected (Figure 3), it was possible that XPC-RAD23B may still stimulate the activity of EcMUG by displacing the glycosylase from the AP site, since XPC itself also seems to have a binding affinity toward the AP site [20]. As shown in Figure 4, however, XPC hardly affected the enzymatic activity of EcMUG; while $0.8 \mathrm{nM} E c \mathrm{MUG}$ processed about $6 \%$ of the substrate DNA $(1.6 \mathrm{nM})$ within 120 minutes, $\sim 9 \%$ of the uracil was removed from the G/U mismatched-DNA in the presence of $4 \mathrm{nM}$ XPC-RAD23B. Although there might be thus a very weak stimulation, the effect of XPC on EcMUG activity was much less pronounced than that on TDG.

3.3. XPC Stimulates the Activity of Sumoylated TDG. A covalent modification of TDG by SUMO-1 was shown to dramatically affect its DNA binding properties [30, 32]. Consequently, TDG appears to lose its activity on G/T mismatches, whereas the excision of uracils from G/U substrates is even enhanced upon sumoylation. The stimulation of the uracil cleavage seemed to be due to relief of TDG from the product inhibition via SUMO-1 conjugation [30].
Given that the sumoylated TDG may not be bound to the AP site so stably, it was of our great interest to know whether XPC can interact with and stimulate the activity of the modified enzyme. To test this idea, we prepared SUMO-1-conjugated TDG by expressing E1 (Aos1-Uba2), E2 (Ubc9), SUMO-1, and TDG (His- or GST-tagged) in E. coli simultaneously, which enables efficient sumoylation of TDG within bacteria [37]. The sumoylated His-TDG (Figure 5(a)) and GST-TDG (data not shown) were purified to near homogeneity. We confirmed that the purified protein specifically reacts with both anti-TDG and anti-SUMO-1 antibodies (Figure 5(b)). Analysis of the protease-digested fragments with mass spectrometry and peptide sequencing further demonstrated that SUMO-1 is conjugated exactly to the predicted site (Lys330 of TDG; data not shown).

At first, we tested a protein-protein interaction between XPC and the sumoylated TDG by GST pull-down assay. As shown in Figure 3, a significant amount of XPC was coprecipitated with SUMO-1-GST-TDG if compared to GST alone, and approximately 2-fold more XPC appeared to bind to SUMO-1-GST-TDG than to nonmodified GSTTDG. This indicates that XPC can bind to TDG regardless of the presence or absence of modification by SUMO-1. We then examined whether XPC can affect the activity of SUMO-1-TDG. As reported by Hardeland et al. [30], the purified recombinant SUMO-1-TDG had only marginal activity for $\mathrm{G} / \mathrm{T}$ mismatches (data not shown). On the other hand, SUMO-1-TDG showed nearly linear kinetics of uracil removal from G/U mismatches up to 120-minute incubation, suggesting that the product inhibition was much less pronounced as described previously (Figure 5(c); [30]). Interestingly, this activity of SUMO-1-TDG was further stimulated by the addition of XPC in a dose-dependent manner (Figure 5(c)). Incubation of $4 \mathrm{nM}$ XPC-RAD23B resulted in $\sim 5$-fold processing of the G/U mismatch in 120 minutes, and this ratio was comparable to the stimulation of nonmodified TDG cleaving the same substrate (Figure 5(c)). Thus, these results demonstrate that XPC can upregulate the activity of not only nonmodified TDG but also SUMO-1modified TDG in vitro.

3.4. Effects of XPC on Other DNA Glycosylases. Since it has been reported that XPC stimulates OGG1 in addition to TDG, we next investigated the effect of XPC on various DNA glycosylases, especially the monofunctional DNA glycosylases that are involved in G/T and/or G/U mismatch repair, including $\mathrm{UNG} 2, \mathrm{MBD} 4$ (also referred to as MED1), and SMUG1. UNG2 and SMUG1 mainly remove uracils not only from double-stranded DNA but also from single-stranded DNA, whereas MBD4 as well as TDG is more or less specialized toward correction of G/T and G/U mismatches particularly in the $\mathrm{CpG}$ context. As shown in Figure 6, XPC showed no obvious effect on the activity of UNG2 against G/U mismatch (Figure 6(a)), that of MBD4 against G/T mismatch (Figure 6(b)), or that of MBD4 against $\mathrm{G} / \mathrm{U}$ mismatch (data not shown). Although the activities of both UNG2 and MBD4 were somewhat reduced in the presence of XPC, this may be due to the nonspecific 

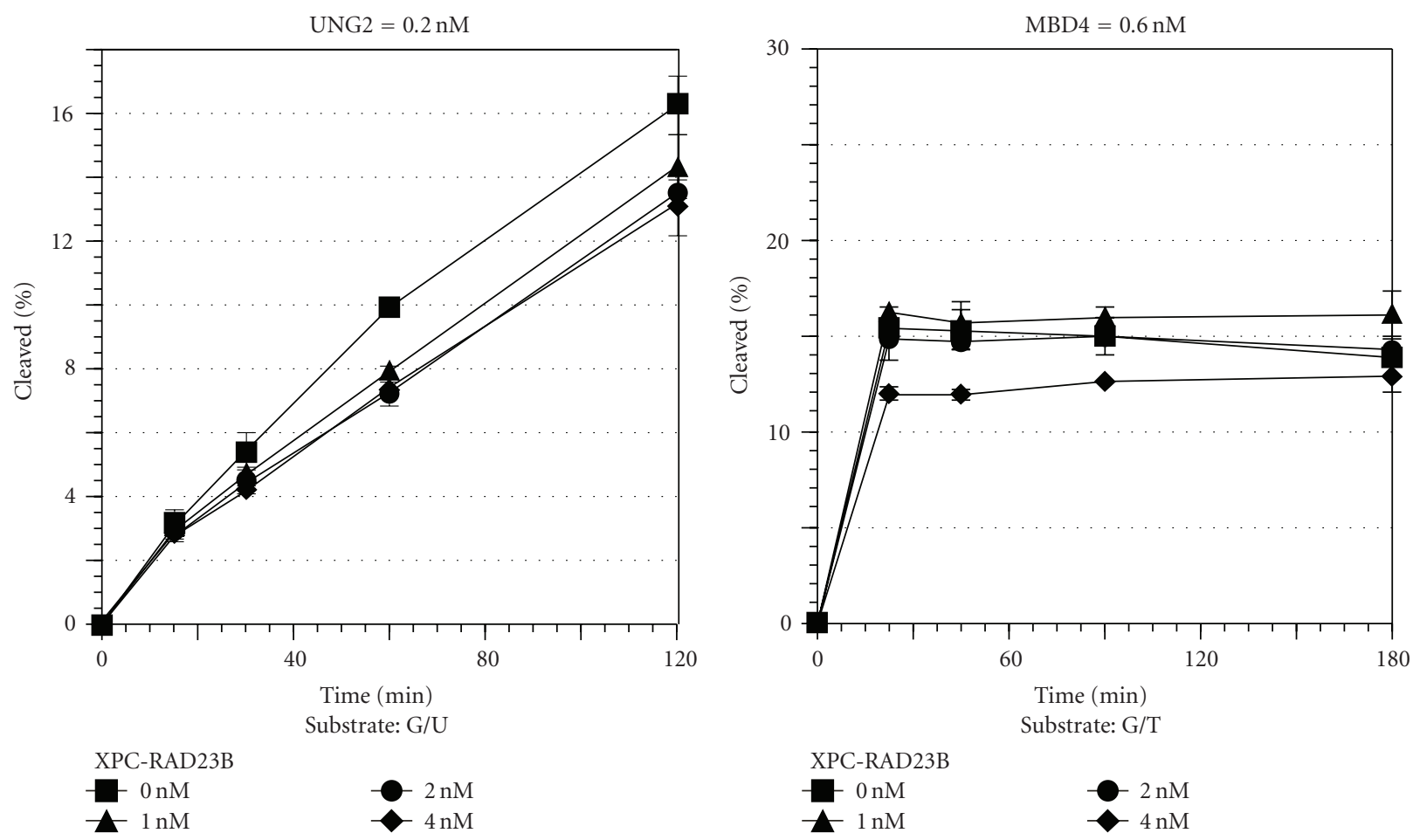

(a)

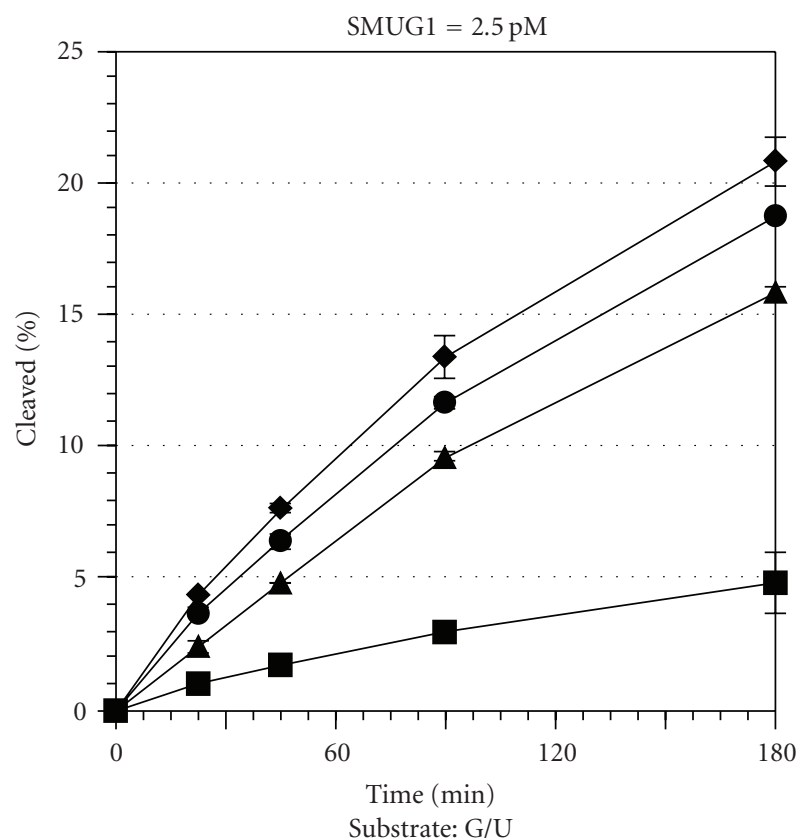

XPC-RAD23B
$-0 \mathrm{nM}$
$-0.5 \mathrm{nM}$

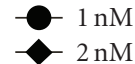

(c)

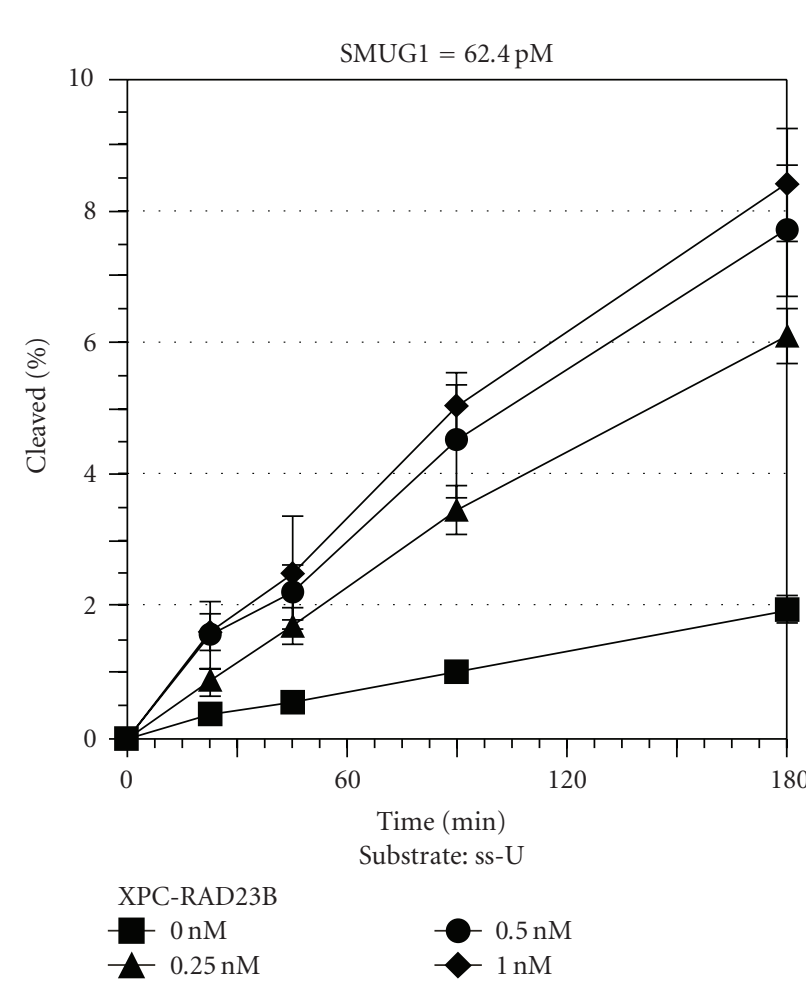

(b)

(d)

FIGURE 6: The effect of XPC on the activity of other DNA glycosylases involved in G/T and/or G/U mismatch repair. The activity of UNG2 (a), MBD4 (b), or SMUG1 ((c) and (d)) was measured in the presence of various amounts of XPC-RAD23B. In each reaction, $1.6 \mathrm{nM}$ of 60-bp DNA containing a single G/U mismatch ((a) and (c)), G/T mismatch (b), or single stranded 30-mer oligonucleotide containing a single uracil residue $(\mathrm{d})$ was used as the substrate. The reaction was done at $30^{\circ} \mathrm{C}$ for the time indicated with specified concentration of purified recombinant proteins as shown. The DNA samples were then purified and subjected to alkali-treatment to cleave the resulting AP sites and separated with denaturing PAGE. The ratio of the cleaved product was calculated and plotted as a graph. The mean values and standard errors were calculated from at least two independent experiments. 


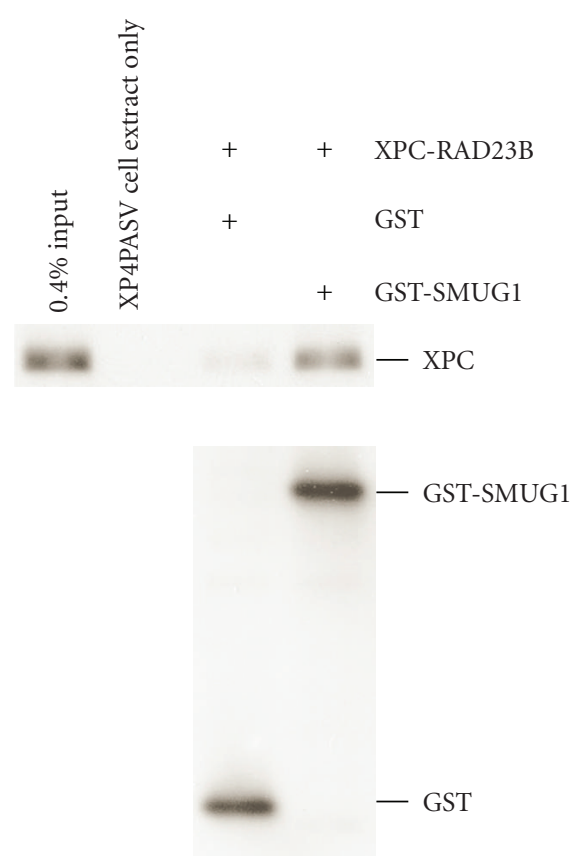

FIGURE 7: XPC interacts physically with SMUG1 in vitro. Glutathione-Sepharose beads $(20 \mu \mathrm{l})$ were incubated in $100 \mu \mathrm{l}$ of the binding mixture with $10 \mathrm{nM}$ of either GST or GST-TDG in the presence of the same concentration of XPC-RAD23B. After extensive washing, bound proteins were eluted with buffer containing $10 \mathrm{mM}$ glutathione. One-fourth of each eluate was mixed with whole cell extract from XP4PASV cells which do not express XPC and subjected to $8 \%$ SDS-PAGE followed by immunoblotting with anti-XPC antibody (upper panel). The same samples were also subjected to $12 \%$ SDS-PAGE followed by immunoblotting with anti-GST antibody (lower panel).

binding of XPC to DNA. On the contrary, XPC showed a striking stimulation on the activity of SMUG1 against G/U mismatch in a dose-dependent manner (Figure 6(c)). In the absence of XPC, $2.5 \mathrm{pM}$ SMUG1 processed about $5 \%$ of $1.6 \mathrm{nM}$ G/U-mismatched DNA in 120 minutes under the conditions tested. Meanwhile, the presence of $2 \mathrm{nM}$ XPCRAD23B boosted the SMUG1 activity up to 4 -fold under the equivalent conditions. This stimulation was also observed when a single-stranded 30-mer oligonucleotide containing a single uracil residue was used as a substrate (Figures 1 and $6(\mathrm{~d}))$. While $62.4 \mathrm{pM}$ SMUG1 cleaved about $2 \%$ of the substrate $(1.6 \mathrm{nM})$ in 120 minutes, addition of $1 \mathrm{nM}$ XPC-RAD23B stimulated the cleavage up to $8 \%$ under the same conditions. Although SMUG1 is known to remove uracils more efficiently from single-stranded DNA than from double-stranded DNA, our results showed the opposite pattern. This might be due to the difference in length of the substrate DNA between G/U-mismatched double-stranded DNA (60 bp) and single-stranded DNA (30 mer) [39]. These results suggest that XPC functionally interacts not only with TDG but also with SMUG1.

3.5. XPC Physically Interacts with SMUG1. Since our results indicate that XPC could stimulate the activity of SMUG1 in vitro, we tested the existence of the protein-protein interaction between XPC and SMUG1 by using the GST-pull down assay (Figure 7). Ten nanomolar each of GST or GSTfused SMUG1 was incubated with an equimolar amount of XPC-RAD23B, and then bound to the glutathione-Sepharose beads. After eluting the bound protein with glutathione, the presence of GST and GST-SMUG1 or XPC was visualized by immunoblotting using anti-GST or anti-XPC antibody, respectively. While equivalent molar amounts of GST and GST-SMUG1 were observed within the eluates, only little amount of XPC was bound to the control GST. On the other hand, a significant amount of XPC was pulleddown with GST-SMUG1. Although this protein-protein interaction seems to be relatively weak (only $\sim 0.4 \%$ of the input was bound to XPC), these results indicate presence of a direct interaction between XPC and SMUG1.

\section{Discussion}

4.1. Mechanistic Implications on the Enzymatic Turnover of TDG Promoted by XPC. In this study, we have further examined the molecular mechanisms of interaction between XPC and TDG that facilitate the enzymatic turnover of TDG. In our previous studies, XPC appeared to promote dissociation of TDG from the AP site that is generated by its own glycosylase activity on G/T mismatch [20]. At least two possible mechanisms have been considered, which could contribute to the displacement of TDG from the abasic reaction product: (1) protein-protein interaction between XPC and TDG weakens the binding affinity of TDG to the substrate DNA, and (2) XPC and TDG compete for the same AP site, and thus TDG is pushed out. In order to examine which factor is more critical for the enhanced enzymatic turnover, EcMUG, an E. coli homolog of mammalian TDG, was utilized as a model that can bind to the AP site as well as TDG $[24,25]$ but cannot interact with XPC (Figure 3). Our results indicate that the stimulation of EcMUG by XPC is almost negligible when compared to human TDG (Figure 4). Although there might be very weak stimulation of EcMUG, which could be due to competitive displacement of the enzyme from the AP site by XPC-RAD23B, these results point to importance of the protein-protein interaction for the stimulation of TDG by XPC. In agreement with this idea, we show here that XPC also stimulates the activities of sumoylated TDG and SMUG1, both of which interact physically with XPC (Figures 3 and 7).

Our present data also indicate that very stable association of DNA glycosylase with the produced AP site is not a prerequisite for stimulation by XPC. It has been reported that modification of TDG by SUMO alters its structure in the C-terminal domain, which leads to the release of TDG from the AP site and therefore induces accelerated enzymatic turnover [30-32]. In fact, in contrast to the immediately saturating reaction patterns of unmodified TDG, the sumoylated enzyme exhibited a nearly linear kinetics of uracil removal from G/U mismatches. Even under these conditions, intriguingly, XPC has an ability to further stimulate the activity of SUMO-1-TDG. It is possible that, 
like the reported case for OGG1, XPC may stimulate loading of certain DNA glycosylases to substrate DNA. Although competition with XPC for the AP site may not be sufficient by itself to displace the tightly bound DNA glycosylase, our data do not exclude that the binding affinity of XPC to the AP site may still contribute to promotion of the enzymatic turnover. Considering the fact that XPC and APE1 stimulate the activity of TDG in an additive fashion [20] and that APE1 also further stimulates the activity of SUMO-1-TDG [30], XPC, sumoylation, and APE1 might be collaborating to control the repair of G/T and G/U mismatches positively in vivo. To understand the relationship between these three factors in detail, in vivo regulation of the TDG sumoylation should be clarified in the future experiments. In addition, it has been shown that XPC undergoes in vivo posttranslational modifications, such as ubiquitylation [40, 41], sumoylation [41], and phosphorylation [42, 43]. Although the observed stimulation of DNA glycosylases seemed to occur in the absence of these modifications, it is still possible that one or more of these modifications may affect interaction with and/or stimulation of some DNA glycosylases. Future studies would be necessary to address such intriguing possibility.

4.2. Possible Roles of Interactions between XPC and TDG/ SMUG1 in Prevention of Mutagenesis and Carcinogenesis. Mammalian cells contain at least four nuclear DNA glycosylases that can correct G/U and/or G/T mismatches, that is, TDG, UNG2, MBD4, and SMUG1. Although precise niche for each of these DNA glycosylases remains to be clarified, their biological roles have been suggested through observations of in vivo behaviors and through interacting partners. UNG2 seems to be specialized in counteracting U:A base pairs formed by misincorporation of dUTP during DNA replication. Among the uracil-DNA glycosylases, only UNG2 specifically accumulates in the replication foci during the $\mathrm{S}$ phase, thereby colocalizing with proliferating cell nuclear antigen (PCNA) and RPA [44]. On the other hand, SMUG1 was first identified by in vitro expression cloning [39] and also independently found to be a backup enzyme for UNG2 [45, 46]. Unlike UNG2, SMUG1 may account for the repair of replication-independent premutagenic $G / U$ mispairs resulting from cytosine deamination in vivo, since it is expressed similarly in nonproliferating and proliferating cells [45] and it does not colocalize with PCNA during the S phase [47]. TDG and MBD4 apparently have very similar substrate specificities: $\mathrm{G} / \mathrm{T}$ and $\mathrm{G} / \mathrm{U}$ mispairs that are spontaneously generated by deamination of cytosines in CpG dinucleotides. Besides its function in BER, TDG is also known to interact with and regulate several transcription factors [48-51]. MBD4 interacts with a mismatch repair protein MLH1 [52], which may be involved in regulation of some DNA damage response pathways [53]. Interestingly, human UNG, TDG, and SMUG1 genes are closely located within the long arm of chromosome 12, and these genes are believed to be the derivatives from an identical ancestral gene [54]. In fact, structural studies revealed that they contain several common folds despite rather low $(\sim 10 \%)$ amino acid sequence homology $[55,56]$. In these points of view, TDG and SMUG1 might still possess the common surface that might be the remnant of the ancestor to interact with XPC.

It has been reported that TDG is able to process certain oxidative pyrimidine lesions, such as thymine glycol, 5hydroxyuracil, and 5-hydroxymethyluracil, when paired with guanine [21]. In addition, SMUG1 was shown to be a primary repair enzyme for a subset of oxidized uracil derivatives such as 5-formyluracil, 5-hydroxymethyluracil, and 5hydroxyuracil in both single- and double-stranded DNA [57, 58]. Taken together with the recent report showing that XPC stimulates the activity of OGG1 [33], these findings suggest that XPC might be involved in repair of diverse oxidative DNA lesions. In fact, lack of endogenous XPC seems to result in inefficient repair of spontaneous oxidative DNA damage. Interestingly, while a significant amount of $\mathrm{H}_{2} \mathrm{O}_{2}$ is produced upon UV irradiation in most of the complementation groups of the XP cells including XP-C compared to normal cells [59], plasmid reactivation assays revealed that only XP-C cells exhibited markedly reduced repair capacity for some singlet oxygen-induced DNA lesions [60]. Furthermore, extensive mutational analyses of the Trp53 of UVB-induced skin tumors in $\mathrm{Xpc}^{-/-}$mice revealed a mutational hotspot at a nondipyrimidinic CpG site in codon $122[61,62]$. At this site, $\mathrm{C}$ to $\mathrm{T}$ transition has been frequently detected specifically in $\mathrm{Xpc}^{-/-}$mice (not in $\mathrm{Xpa}^{-/-}$or $\mathrm{Csa}^{-/-}$mice), which is plausibly explained by reduced TDG activity in the absence of functional XPC protein. However, the tandem mutations $\mathrm{AC}>\mathrm{TT}$ and $\mathrm{AC}>\mathrm{CT}$ have been also found at the same site, which cannot be attributed either to UVinduced dipyrimidinic photolesions or to deamination of the cytosine alone. In addition, it has been reported that agedependent spontaneous mutations significantly accumulate in $X p c^{-/-}$mice even without UV exposure [63], and $p 53$ gene mutations were identified in internal tumors of XP$\mathrm{C}$ patients [64]. Many of these mutations are less likely to be the result of defects in correction of G/T and/or $\mathrm{G} / \mathrm{U}$ mismatches. It could be possible that impaired repair of certain types of oxidative damage may be involved in occurrence of these mutations.

\section{Conclusions}

Here we show that XPC stimulates activities of a certain spectrum of DNA glycosylases, for which protein-protein interactions seem to be important, rather than competition for AP sites. In order to clarify the significance of interaction between XPC and TDG or SMUG1 in vivo, it should be necessary to understand the precise physiological roles of the different thymine- and uracil-DNA glycosylases. Further studies would reveal novel and important aspects in understanding the mutagenesis and carcinogenesis in XP-C patients.

\section{Acknowledgments}

The authors thank L. Lan, M. Takao, and A. Yasui (Tohoku University) for MBD4 cDNA and purified NEIL1 protein and M. Shirakawa (Kyoto University) for information on the 
sumoylation system in bacteria. This work was supported by Grants-in-Aid from the Ministry of Education, Culture, Sports, Science and Technology of Japan.

\section{References}

[1] E. C. Friedberg, G. C. Walker, W. Siede, R. D. Wood, R. A. Schultz, and T. Ellenberger, DNA Repair and Mutagenesis, ASM Press, Washington, DC, USA, 2nd edition, 2006.

[2] A. K. McCullough, M. L. Dodson, and R. S. Lloyd, "Initiation of base excision repair: glycosylase mechanisms and structures," Annual Review of Biochemistry, vol. 68, pp. 255-285, 1999.

[3] O. D. Schärer and J. Jiricny, "Recent progress in the biology, chemistry and structural biology of DNA glycosylases," BioEssays, vol. 23, no. 3, pp. 270-281, 2001.

[4] D. Bootsma, K. H. Kraemer, J. E. Cleaver, and J. H. J. Hoeijmakers, "Nucleotide excision repair syndromes: xeroderma pigmentosum, Cockayne syndrome, and trichothiodystrophy," in The Metabolic and Molecular Basis of Inherited Disease, C. R. Scriver, A. L. Beaudet, W. S. Sly, and D. Valle, Eds., pp. 677-703, McGraw-Hill, New York, NY, USA, 2001.

[5] T. Riedl, F. Hanaoka, and J.-M. Egly, "The comings and goings of nucleotide excision repair factors on damaged DNA," EMBO Journal, vol. 22, no. 19, pp. 5293-5303, 2003.

[6] K. Sugasawa, J. M. Y. Ng, C. Masutani et al., "Xeroderma pigmentosum group $\mathrm{C}$ protein complex is the initiator of global genome nucleotide excision repair," Molecular Cell, vol. 2, no. 2, pp. 223-232, 1998.

[7] M. Volker, M. J. Moné, P. Karmakar et al., "Sequential assembly of the nucleotide excision repair factors in vivo," Molecular Cell, vol. 8, no. 1, pp. 213-224, 2001.

[8] M. Araki, C. Masutani, M. Takemura et al., "Centrosome protein centrin $2 /$ caltractin 1 is part of the xeroderma pigmentosum group $\mathrm{C}$ complex that initiates global genome nucleotide excision repair," The Journal of Biological Chemistry, vol. 276, no. 22, pp. 18665-18672, 2001.

[9] C. Masutani, K. Sugasawa, J. Yanagisawa et al., "Purification and cloning of a nucleotide excision repair complex involving the xeroderma pigmentosum group $\mathrm{C}$ protein and a human homologue of yeast RAD23," EMBO Journal, vol. 13, no. 8, pp. 1831-1843, 1994.

[10] M. K. K. Shivji, A. P. M. Eker, and R. D. Wood, "DNA repair defect in xeroderma pigmentosum group $\mathrm{C}$ and complementing factor from HeLa cells," The Journal of Biological Chemistry, vol. 269, no. 36, pp. 22749-22757, 1994.

[11] J. M. Y. Ng, W. Vermeulen, G. T. J. van der Horst et al., "A novel regulation mechanism of DNA repair by damage-induced and RAD23-dependent stabilization of xeroderma pigmentosum group C protein," Genes and Development, vol. 17, no. 13, pp. 1630-1645, 2003.

[12] Y. Okuda, R. Nishi, J. M. Y. Ng et al., "Relative levels of the two mammalian Rad23 homologs determine composition and stability of the xeroderma pigmentosum group $\mathrm{C}$ protein complex," DNA Repair, vol. 3, no. 10, pp. 1285-1295, 2004.

[13] S. J. Araújo, F. Tirode, F. Coin et al., "Nucleotide excision repair of DNA with recombinant human proteins: definition of the minimal set of factors, active forms of TFIIH, and modulation by CAK," Genes and Development, vol. 14, no. 3, pp. 349-359, 2000.

[14] D. Mu, C.-H. Park, T. Matsunaga, D. S. Hsu, J. T. Reardon, and A. Sancar, "Reconstitution of human DNA repair excision nuclease in a highly defined system," The Journal of Biological Chemistry, vol. 270, no. 6, pp. 2415-2418, 1995.

[15] R. Nishi, Y. Okuda, E. Watanabe et al., "Centrin 2 stimulates nucleotide excision repair by interacting with xeroderma pigmentosum group C protein," Molecular and Cellular Biology, vol. 25, no. 13, pp. 5664-5674, 2005.

[16] J.-H. Min and N. P. Pavletich, "Recognition of DNA damage by the Rad4 nucleotide excision repair protein," Nature, vol. 449, no. 7162, pp. 570-575, 2007.

[17] K. Sugasawa, T. Okamoto, Y. Shimizu, C. Masutani, S. Iwai, and F. Hanaoka, "A multistep damage recognition mechanism for global genomic nucleotide excision repair," Genes and Development, vol. 15, no. 5, pp. 507-521, 2001.

[18] K. Sugasawa, Y. Shimizu, S. Iwai, and F. Hanaoka, "A molecular mechanism for DNA damage recognition by the xeroderma pigmentosum group C protein complex," DNA Repair, vol. 1, no. 1, pp. 95-107, 2002.

[19] L. C. J. Gillet and O. D. Schärer, "Molecular mechanisms of mammalian global genome nucleotide excision repair," Chemical Reviews, vol. 106, no. 2, pp. 253-276, 2006.

[20] Y. Shimizu, S. Iwai, F. Hanaoka, and K. Sugasawa, "Xeroderma pigmentosum group $\mathrm{C}$ protein interacts physically and functionally with thymine DNA glycosylase," EMBO Journal, vol. 22, no. 1, pp. 164-173, 2003.

[21] D. Cortázar, C. Kunz, Y. Saito, R. Steinacher, and P. Schär, "The enigmatic thymine DNA glycosylase," DNA Repair, vol. 6, no. 4, pp. 489-504, 2007.

[22] T. R. Waters, P. Gallinari, J. Jiricnyl, and P. F. Swann, "Human thymine DNA glycosylase binds to apurinic sites in DNA but is displaced by human apurinic endonuclease 1," The Journal of Biological Chemistry, vol. 274, no. 1, pp. 67-74, 1999.

[23] T. R. Waters and P. F. Swann, "Kinetics of the action of thymine DNA glycosylase," The Journal of Biological Chemistry, vol. 273, no. 32, pp. 20007-20014, 1998.

[24] T. E. Barrett, R. Savva, G. Panayotou et al., "Crystal structure of a G:T/U mismatch-specific DNA glycosylase: mismatch recognition by complementary-strand interactions," Cell, vol. 92, no. 1, pp. 117-129, 1998.

[25] T. E. Barrett, O. D. Schärer, R. Savva et al., "Crystal structure of a thwarted mismatch glycosylase DNA repair complex," EMBO Journal, vol. 18, no. 23, pp. 6599-6609, 1999.

[26] U. Hardeland, M. Bentele, J. Jiricny, and P. Schar, "Separating substrate recognition from base hydrolysis in human thymine DNA glycosylase by mutational analysis," The Journal of Biological Chemistry, vol. 275, no. 43, pp. 33449-33456, 2000.

[27] M. Abu and T. R. Waters, "The main role of human thymineDNA glycosylase is removal of thymine produced by deamination of 5-methylcytosine and not removal of ethenocytosine," The Journal of Biological Chemistry, vol. 278, no. 10, pp. 87398744, 2003.

[28] M. E. Fitzgerald and A. C. Drohat, "Coordinating the initial steps of base excision repair: apurinic/apyrimidinic endonuclease 1 actively stimulates thymine DNA glycosylase by disrupting the product complex," The Journal of Biological Chemistry, vol. 283, no. 47, pp. 32680-32690, 2008.

[29] C. V. Privezentzev, M. Saparbaev, and J. Laval, "The HAP1 protein stimulates the turnover of human mismatch-specific thymine-DNA-glycosylase to process 3,N4-ethenocytosine residues," Mutation Research, vol. 480-481, pp. 277-284, 2001.

[30] U. Hardeland, R. Steinacher, J. Jiricny, and P. Schär, "Modification of the human thymine-DNA glycosylase by ubiquitin-like proteins facilitates enzymatic turnover," EMBO Journal, vol. 21, no. 6, pp. 1456-1464, 2002. 
[31] D. Baba, N. Maita, J.-G. Jee et al., "Crystal structure of thymine DNA glycosylase conjugated to SUMO-1," Nature, vol. 435, no. 7044, pp. 979-982, 2005.

[32] R. Steinacher and P. Schär, "Functionality of human thymine DNA glycosylase requires SUMO-regulated changes in protein conformation," Current Biology, vol. 15, no. 7, pp. 616-623, 2005.

[33] M. D'Errico, E. Parlanti, M. Teson et al., "New functions of XPC in the protection of human skin cells from oxidative damage," EMBO Journal, vol. 25, no. 18, pp. 4305-4315, 2006.

[34] C. Masutani, M. Araki, K. Sugasawa et al., "Identification and characterization of XPC-binding domain of hHR23B," Molecular and Cellular Biology, vol. 17, no. 12, pp. 6915-6923, 1997.

[35] K. Sugasawa, C. Masutani, A. Uchida et al., "HHR23B, a human Rad23 homolog, stimulates XPC protein in nucleotide excision repair in vitro," Molecular and Cellular Biology, vol. 16, no. 9, pp. 4852-4861, 1996.

[36] K. Kino, Y. Shimizu, K. Sugasawa, H. Sugiyama, and F. Hanaoka, "Nucleotide excision repair of 5-formyluracil in vitro is enhanced by the presence of mismatched bases," Biochemistry, vol. 43, no. 10, pp. 2682-2687, 2004.

[37] Y. Uchimura, M. Nakamura, K. Sugasawa, M. Nakao, and H. Saitoh, "Overproduction of eukaryotic SUMO-1- and SUMO-2-conjugated proteins in Escherichia col," Analytical Biochemistry, vol. 331, no. 1, pp. 204-206, 2004.

[38] P. Gallinari and J. Jiricny, "A new class of uracil-DNA glycosylases related to human thymine-DNA glycosylase," Nature, vol. 383, no. 6602, pp. 735-738, 1996.

[39] K. A. Haushalter, P. T. Stukenberg, M. W. Kirschner, and G. L. Verdine, "Identification of a new uracil-DNA glycosylase family by expression cloning using synthetic inhibitors," Current Biology, vol. 9, no. 4, pp. 174-185, 1999.

[40] K. Sugasawa, Y. Okuda, M. Saijo et al., "UV-induced ubiquitylation of XPC protein mediated by UV-DDB-ubiquitin ligase complex," Cell, vol. 121, no. 3, pp. 387-400, 2005.

[41] Q.-E. Wang, Q. Zhu, G. Wani, M. A. El-Mahdy, J. Li, and A. A. Wani, "DNA repair factor XPC is modified by SUMO-1 and ubiquitin following UV irradiation," Nucleic Acids Research, vol. 33, no. 13, pp. 4023-4034, 2005.

[42] S. A. Beausoleil, M. Jedrychowski, D. Schwartz et al., "Largescale characterization of HeLa cell nuclear phosphoproteins," Proceedings of the National Academy of Sciences of the United States of America, vol. 101, no. 33, pp. 12130-12135, 2004.

[43] S. Matsuoka, B. A. Ballif, A. Smogorzewska et al., "ATM and ATR substrate analysis reveals extensive protein networks responsive to DNA damage," Science, vol. 316, no. 5828, pp. 1160-1166, 2007.

[44] M. Otterlei, E. Warbrick, T. A. Nagelhus et al., "Post-replicative base excision repair in replication foci," EMBO Journal, vol. 18, no. 13, pp. 3834-3844, 1999.

[45] H. Nilsen, K. A. Haushalter, P. Robins, D. E. Barnes, G. L. Verdine, and T. Lindahl, "Excision of deaminated cytosine from the vertebrate genome: role of the SMUG1 uracil-DNA glycosylase," EMBO Journal, vol. 20, no. 15, pp. 4278-4286, 2001.

[46] H. Nilsen, I. Rosewell, P. Robins et al., "Uracil-DNA glycosylase (UNG)-deficient mice reveal a primary role of the enzyme during DNA replication," Molecular Cell, vol. 5, no. 6, pp. 1059-1065, 2000.

[47] B. Kavli, O. Sundheim, M. Akbari et al., "hUNG2 is the major repair enzyme for removal of uracil from U:A matches, U:G mismatches, and $U$ in single-stranded DNA, with hSMUG1 as a broad specificity backup," The Journal of Biological Chemistry, vol. 277, no. 42, pp. 39926-39936, 2002.

[48] D. Chen, M. J. Lucey, F. Phoenix et al., "T:G mismatchspecific thymine-DNA glycosylase potentiates transcription of estrogen-regulated genes through direct interaction with estrogen receptor $\alpha$," The Journal of Biological Chemistry, vol. 278, no. 40, pp. 38586-38592, 2003.

[49] C. Missero, M. T. Pirro, S. Simeone, M. Pischetola, and R. Di Lauro, "The DNA glycosylase T:G mismatch-specific thymine DNA glycosylase represses thyroid transcription factor-1activated transcription," The Journal of Biological Chemistry, vol. 276, no. 36, pp. 33569-33575, 2001.

[50] M. Tini, A. Benecke, S.-J. Um, J. Torchia, R. M. Evans, and P. Chambon, "Association of CBP/p300 acetylase and thymine DNA glycosylase links DNA repair and transcription," Molecular Cell, vol. 9, no. 2, pp. 265-277, 2002.

[51] S. Um, M. Harbers, A. Benecke, B. Pierrat, R. Losson, and P. Chambon, "Retinoic acid receptors interact physically and functionally with the T:G mismatch-specific thymine-DNA glycosylase," The Journal of Biological Chemistry, vol. 273, no. 33, pp. 20728-20736, 1998.

[52] A. Bellacosa, L. Cicchillitti, F. Schepis et al., "MED1, a novel human methyl-CpG-binding endonuclease, interacts with DNA mismatch repair protein MLH1," Proceedings of the National Academy of Sciences of the United States of America, vol. 96, no. 7, pp. 3969-3974, 1999.

[53] S. Cortellino, D. Turner, V. Masciullo et al., "The base excision repair enzyme MED1 mediates DNA damage response to antitumor drugs and is associated with mismatch repair system integrity," Proceedings of the National Academy of Sciences of the United States of America, vol. 100, no. 25, pp. 15071-15076, 2003.

[54] H. E. Krokan, M. Otterlei, H. Nilsen et al., "Properties and functions of human uracil-DNA glycosylase from the UNG gene," Progress in Nucleic Acid Research and Molecular Biology, vol. 68, pp. 365-386, 2001.

[55] L. H. Pearl, "Structure and function in the uracil-DNA glycosylase superfamily," Mutation Research, vol. 460, no. 3-4, pp. 165-181, 2000.

[56] J. E. A. Wibley, T. R. Waters, K. Haushalter, G. L. Verdine, and L. H. Pearl, "Structure and specificity of the vertebrate antimutator uracil-DNA glycosylase SMUG1," Molecular Cell, vol. 11, no. 6, pp. 1647-1659, 2003.

[57] R. J. Boorstein, A. Cummings Jr., D. R. Marenstein et al., "Definitive Identification of Mammalian 5Hydroxymethyluracil DNA N-Glycosylase Activity as SMUG1," The Journal of Biological Chemistry, vol. 276, no. 45, pp. 41991-41997, 2001.

[58] A. Masaoka, M. Matsubara, R. Hasegawa et al., "Mammalian 5-formyluracil-DNA glycosylase. 2. Role of SMUG1 uracilDNA glycosylase in repair of 5-formyluracil and other oxidized and deaminated base lesions," Biochemistry, vol. 42, no. 17, pp. 5003-5012, 2003.

[59] M. Vuillaume, L. Daya-Grosjean, P. Vincens et al., "Striking differences in cellular catalase activity between two DNA repair-deficient diseases: xeroderma pigmentosum and trichothiodystrophy," Carcinogenesis, vol. 13, no. 3, pp. 321-328, 1992.

[60] T. M. Runger, B. Epe, and K. Moller, "Repair of Ultraviolet $\mathrm{B}$ and singlet oxygen-induced DNA damage in xeroderma pigmentosum cells," Journal of Investigative Dermatology, vol. 104, no. 1, pp. 68-73, 1995.

[61] D. Nahari, L. D. McDaniel, L. B. Task, R. L. Daniel, S. VelascoMiguel, and E. C. Friedberg, "Mutations in the Trp53 gene 
of UV-irradiated Xpc mutant mice suggest a novel Xpcdependent DNA repair process," DNA Repair, vol. 3, no. 4, pp. 379-386, 2004.

[62] A. M. Reis, D. L. Cheo, L. B. Meira et al., "Genotype-specific Trp53 mutational analysis in ultraviolet B radiation- induced skin cancers in Xpc and Xpc Trp53 mutant mice," Cancer Research, vol. 60, no. 6, pp. 1571-1579, 2000.

[63] S. W. P. Wijnhoven, H. J. M. Kool, L. H. F. Mullenders et al., "Age-dependent spontaneous mutagenesis in Xpc mice defective in nucleotide excision repair," Oncogene, vol. 19, no. 43, pp. 5034-5037, 2000.

[64] G. Giglia, N. Dumaz, C. Drougard, M.-F. Avril, L. DayaGrosjean, and A. Sarasin, "p53 Mutations in skin and internal tumors of xeroderma pigmentosum patients belonging to the complementation group C," Cancer Research, vol. 58, no. 19, pp. 4402-4409, 1998. 

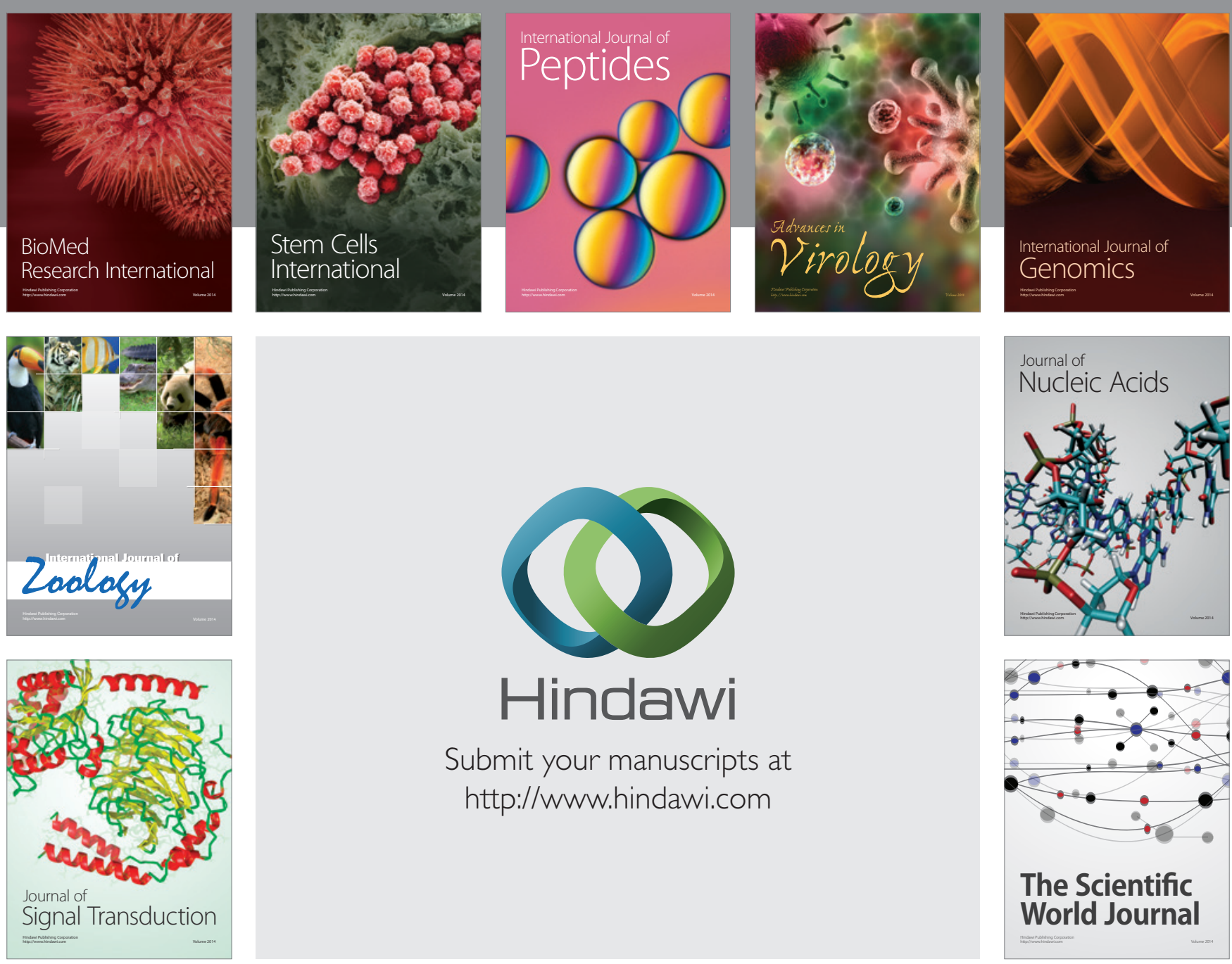

Submit your manuscripts at

http://www.hindawi.com
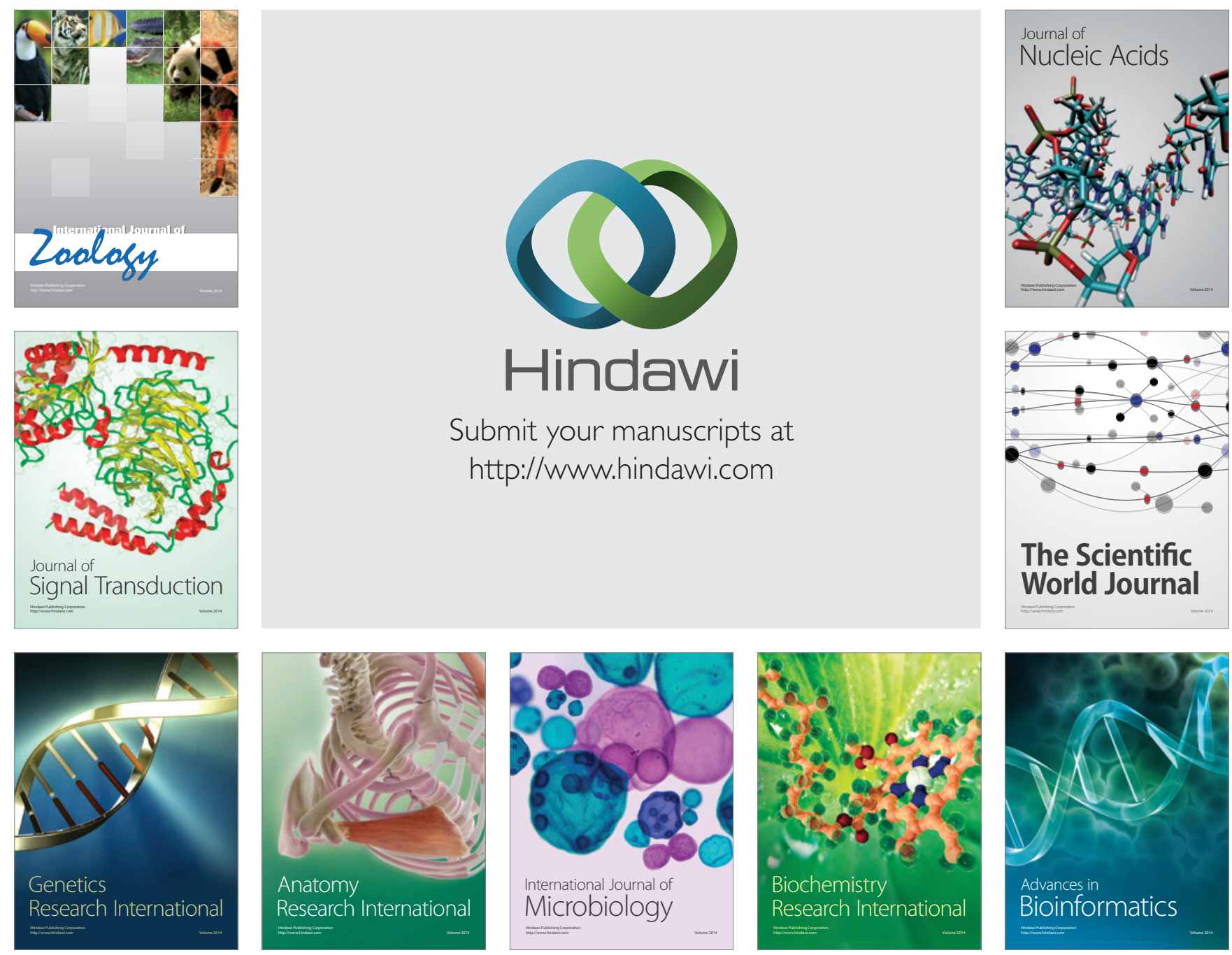

The Scientific World Journal
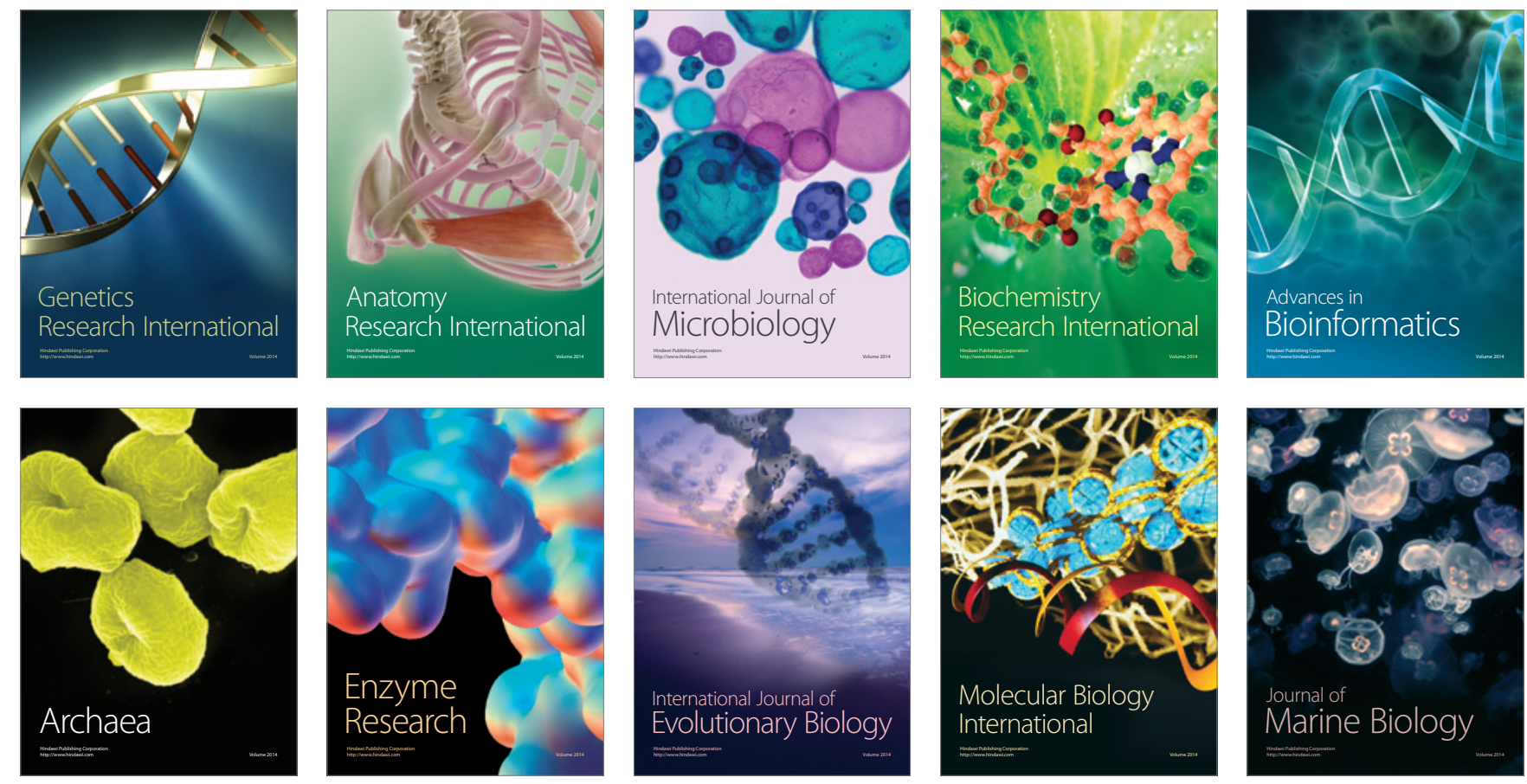